\title{
Correlation of biomarkers and bone mineral density for osteoporosis in post-menopausal women
}

\author{
K. Hymavathi*, Tejaswini Jakka, Bhaavya Paturi
}

Department of Obstetrics and Gynaecology, Narayana Medical College and Hospital, Nellore, Andhra Pradesh, India

Received: 01 December 2019

Accepted: 02 January 2020

\section{*Correspondence:}

Dr. K. Hymavathi,

E-mail: research.nmch@rediffmail.com

Copyright: (C) the author(s), publisher and licensee Medip Academy. This is an open-access article distributed under the terms of the Creative Commons Attribution Non-Commercial License, which permits unrestricted non-commercial use, distribution, and reproduction in any medium, provided the original work is properly cited.

\begin{abstract}
Background: Osteoporosis is a metabolic bone disorder characterised by a low bone mass and microarchitectural deterioration of bone tissue followed by enhanced bone fragility and a consequent rise in fracture risk. Aim of the study is to correlate the biomarkers and bone mineral density in postmenopausal osteoporosis.

Methods: This is a prospective study done in the department of obstetrics and gynaecology, Narayana medical College and Hospital, Nellore for a period of 2 years (October 2016-October 2018). This study was designed to assess the correlation between bone mineral density (BMD) and various biochemical markers.

Results: The mean age of the present study is $60.51 \pm 9.35$ years. There is a significant correlation found between age, serum phosphorus, urinary OHPr and bone mineral density. The mean BMI of the present study is $24.75 \pm 4.25 \mathrm{~kg} / \mathrm{m}^{2}$. There is a significant correlation observed between BMI, serum ionized calcium, urinary OHPr and bone mineral density. There exists a significant correlation between BMD and urinary OHPr. It is found that in menopausal women spine and hip are the major sites affected by osteoporosis. The early changes are found in lumbar spine compared to hip. In the present study with increase in BMI there is increase in BMD signifying obesity is a protective factor for osteoporosis leaving aside all it's ill effects. Urinary hydroxyproline a marker of resorption is found to have a negative correlation with BMD.

Conclusions: BMD measurements using DEXA are not readily available in India. Biochemical markers of bone remodelling are useful tools in assessment of osteoporosis and are safe, inexpensive, easily performed. In the present study an attempt is made to correlate biochemical markers and BMD so as to detect osteoporosis even before the changes being evident on imaging studies.
\end{abstract}

Keywords: Bone mineral density, Dual-energy X-ray, Postmenopausal osteoporosis, Urinary excretion of hydroxyproline

\section{INTRODUCTION}

Osteoporosis is a metabolic bone disorder characterised by a low bone mass and microarchitectural deterioration of bone tissue followed by enhanced bone fragility and a consequent rise in fracture risk. In postmenopausal women, osteoporotic fractures are more common than stroke, myocardial infarction and breast cancer combined and fractures can result in disability and death. ${ }^{1}$
The rate of osteoporosis is higher in Asian population, and it has been estimated that about $50 \%$ of people will be victims of osteoporosis by $2050 .^{2}$ With the onset of menopause, there is rapid bone loss, believed to be approximately $2 \%-3 \%$ over the following 5-10 years, and this is greatest in the early postmenopausal years. ${ }^{3}$

A preventive strategy should ideally be initiated before the occurrence of fractures. Thus, it is important to 
identify postmenopausal women who have low bone mass and high fracture risk to provide preventive and pharmacological therapy.

Bone mineral density (BMD) assessment measured by dual energy X-ray absorptiometry (DEXA) is an independent predictor of fracture risk in postmenopausal women, about one half of the patients with incident fractures have BMD values above the operating diagnostic threshold for osteoporosis. ${ }^{4}$ Biochemical markers of bone turnover provide a means of evaluating skeletal dynamics that complements static measurements of BMD by DEXA. Hence, the present study aimed to correlate the efficacy of biochemical markers of bone turnover with that of bone mineral density by BMD for detecting postmenopausal osteoporosis.

\section{METHODS}

This is a hospital based prospective study conducted in the department of obstetrics and gynaecology, Narayana Medical College and Hospital, Nellore for a period of 2 years from October 2016 to October 2018.

A total 100 postmenopausal women attending gynaecology outpatient department, Narayana medical college and Hospital, Nellore have been included in this study.

\section{Inclusion criteria}

- All postmenopausal women (natural/surgical) who attained menopause $>1$ year.

\section{Exclusion criteria}

- Those suffering from active infectious diseases

- More than two months of confinement to bed

- History of cancer

- History of hormonal replacement therapy

- History of consumption of long-term steroids

- History of Cushing's syndrome

- Those suffering from chronic diseases

- Bone disorders.

Institutional ethical committee of Narayana medical college and Hospital, Nellore, Andhra Pradesh has approved the study with the following considerations.

- A written consent to be taken from all the subjects after explaining them, regarding the study

- Confidentiality should be maintained.

All postmenopausal patients fulfilling the inclusion and exclusion criteria attending the obstetrics and gynaecology department of Narayana Medical College and Hospital were recruited. Detailed history of all the women involved in the study was noted including history of fractures and all of them were subjected to complete systemic and pelvic examination. Anthropometric measurements were done for every patient by a single person and with the same instrument in the clinic. All the cases were subjected to detailed investigations Including special investigations like BMD and biomarkers.

\section{Variables considered were}

Age, BMI, BMD lumbar spine and BMD hip and various biomarkers like serum calcium, serum ionised calcium, serum alkaline phosphatase, serum albumin, serum phosphorus, urinary hydroxyproline, urinary creatinine.

\section{Anthropometric measurements}

- Parameters such as height, weight and BMI were recorded.

- Weight was measured using a beam balance, to the nearest $0.1 \mathrm{~kg}$ and height to the nearest centimetre, using a measuring tape stuck to the wall.

- BMI was calculated as the weight in kilograms divided by the square of height in meters.

\section{Methodology}

\section{Bone mineral density}

Spine: Lumbar spine from first to fourth lumbar vertebrae

Technique: The patient should be properly positioned such that the spine is centered and straight with both iliac crests being visible. The tops of the iliac crests correspond to the level of L4/L5 intervertebral disc in the vast majority of women. The labelling of lumbar vertebrae should be done from bottom up, utilizing the iliac crests as the L4/L5 landmark.

Hip: T-score is obtained at the femoral neck, total hip, or trochanteric regions. The total hip bone density provides greater precision than the femoral neck only.

Technique: Proper positioning of hip such that the femoral shaft is straight and the lesser trochanter should be barely visible. The femoral neck region should not overlap portions of ischium or the greater trochanter as this can result in falsely elevated BMD.

\section{Biomarkers}

A total of $3 \mathrm{ml}$ of blood sample (random) was collected. Serum is separated immediately by centrifuging for 10 minutes and analysed for total calcium, ionised calcium, phosphorus, albumin, alkaline phosphatase.

Random samples of urine were collected at the same time in a clean plastic bulb and analysed for hydroxyproline and creatinine.

- Serum calcium is measured using CPC AMP method 
- Serum albumin by BCG (Bromocresol Green) method

- Serum phosphorus by dry chemistry method

- Serum alkaline phosphatase by PNP AMP kinetic method

- Serum ionized calcium by spectrophotometry

- Urinary creatinine by JAFFES kinetic method

- Urinary hydroxyproline by modified Neuman and Logan method.

\section{Statistical analysis}

- Data was collected, tabulated and analyzed as shown in the results.

The statistical analysis of the data was done using SPSS package. One-way ANNOVA and Pearson's correlation test was applied to the data in order to find the correlation of various variables.

\section{RESULTS}

In the present study, age distribution ranges from 40-80 years, out of which 7 women were in the age group of 4050 years, 43 women were in the age group of 50-60 years, 29 women were in the age group of 60-70 years and 21 were in the age group of $70-80$ years.

A total 5 women were in underweight group $(<18.5$ $\left.\mathrm{kg} / \mathrm{m}^{2}\right), 47$ women were in normal BMI group (18.5-22.9 $\left.\mathrm{kg} / \mathrm{m}^{2}\right), 39$ women were in over weight group (23.0-24.9 $\left.\mathrm{kg} / \mathrm{m}^{2}\right)$ and 9 were in obese group $\left(>25.0 \mathrm{~kg} / \mathrm{m}^{2}\right)$ (Table 1).

Table 1: Correlation of age with BMI, serum calcium, ionised calcium.

\begin{tabular}{|c|c|c|c|c|c|c|}
\hline Variable & $\begin{array}{l}\text { 40-50 year } \\
(n=7)\end{array}$ & $\begin{array}{l}\text { 50-60 year } \\
(n=43)\end{array}$ & $\begin{array}{l}\text { 60-70 year } \\
(n=29)\end{array}$ & $\begin{array}{l}\text { 70-80 year } \\
(\mathrm{n}=21)\end{array}$ & $\begin{array}{l}\text { Total }(n= \\
100)\end{array}$ & P-value \\
\hline BMI $\left(\mathrm{kg} / \mathrm{m}^{2}\right)$ & $25.65 \pm 1.37$ & $24.57 \pm 2.411$ & $25.86 \pm 5.19$ & $23.28 \pm 5.88$ & $24.75 \pm 4.25$ & $0.181, \mathrm{NS}$ \\
\hline $\begin{array}{l}\text { Serum calcium } \\
(\mathrm{mg} / \mathrm{dl})\end{array}$ & $8.357 \pm 0.304$ & $8.572 \pm 0.393$ & $8.310 \pm 0.529$ & $11.890 \pm 15.609$ & $9.17 \pm 7.16$ & $0.283, \mathrm{NS}$ \\
\hline $\begin{array}{l}\text { Ionized calcium } \\
(\mathrm{mmol} / \mathrm{l})\end{array}$ & $1.031 \pm 0.241$ & $1.044 \pm 0.530$ & $1.0403 \pm 0.507$ & $1.0205 \pm 0.480$ & $1.037 \pm 0.050$ & $0.317, \mathrm{NS}$ \\
\hline
\end{tabular}

NS: Not significant.

Table 2: Pearson correlation of age with all variables.

\begin{tabular}{|c|c|c|c|c|c|c|c|c|c|c|c|}
\hline & & Age & BMI & $\mathbf{S ~ C}$ & IC & SP & ALP & S_ALB & BMD_LS & BMD_HIP & $\begin{array}{l}\text { URI_O } \\
\text { HPr:creat }\end{array}$ \\
\hline \multirow[t]{2}{*}{ Age } & $\begin{array}{l}\text { Pears on } \\
\text { correlation }\end{array}$ & 1 & $\begin{array}{l}- \\
0.030\end{array}$ & 0.165 & $\begin{array}{l}- \\
0.050\end{array}$ & 0.179 & 0.070 & -0.090 & $-0.682 * *$ & $-0.746 * *$ & $0.643 * *$ \\
\hline & Sig & & 0.765 & 0.100 & 0.622 & 0.075 & 0.487 & 0.374 & 0.000 & 0.000 & 0.000 \\
\hline
\end{tabular}

**Correlation is significant at the 0.01 level, *Correlation is significant at the 0.05 level.

In the present study 24 women had a normal BMD ( $\mathrm{T}$ score 0 to $-1 \mathrm{SD}$ ) at the lumbar spine, 45 had osteopenia ( $\mathrm{T}$ score -1 to $-2.5 \mathrm{SD}$ ) and 31 women had osteoporosis ( $\mathrm{T}$ score below $-2.5 \mathrm{SD}$ ) at lumbar spine.

In the present study 52 women had a normal BMD hip (T score 0 to $-1 \mathrm{SD}$ ), 35 were in osteopenic group ( $\mathrm{T}$ score 1 to $-2.5 \mathrm{SD}$ ) and 13 women had osteoporosis ( $\mathrm{T}$ score below $-2.5 \mathrm{SD}$ ) at the hip.

In the present study the mean BMI of the study group was found to be $24.75 \pm 4.25 \mathrm{SD}$ and the correlation between age and BMI is not statistically significant with a P-value of 0.181 .

The mean serum calcium level of the study group was found to be $9.17 \pm 7.16 \mathrm{SD}$ and the correlation between age and serum calcium levels is not statistically significant with a P-value of 0.283 .
The mean ionised calcium level of the study group was found to be $1.037 \pm 0.050$ and the correlation between age and ionised calcium levels is not statistically significant with a P-value of 0.317 .

The mean serum phosphorus level of the study group was found to be $4.402 \pm 0.524$ and the correlation between age and serum phosphorus levels is found to be statistically significant with a P-value of 0.019 .

The mean serum ALP level of the study group was found to be $256.60 \pm 44.614 \mathrm{SD}$ and the correlation between age and ALP is not statistically significant with a P-value of 0.156 .

The mean serum albumin of the study group was found to be 3.693 $\pm 0.287 \mathrm{SD}$ and the correlation between age and serum albumin levels is not statistically significant with a $\mathrm{P}$-value of 0.388 . 
The mean BMD Lumbar spine of the study group was found to be $-1.992 \pm 1.0971$ and the correlation between age and BMD Lumbar spine is found to be statistically significant with a $\mathrm{P}$-value of $<0.0001$.

The mean BMD hip of the study group was found to be $1.141 \pm 0.985$ and the correlation between age and BMD hip is found to be statistically significant with a $\mathrm{P}$ - value of $<0.0001$.

The mean urinary hydroxyproline: creatinine ratio of the study group was found to be $27.354 \pm 5.361$ and the correlation between age and urinary hydroxyproline: creatinine is found to be statistically significant with a $\mathrm{P}$ value of $<0.0001$.

Statistical analysis using pearson correlation shows a significant negative correlation between age and T-score of BMD-lumbar spine and BMD-hip which is statistically significant (P-value < 0.0001) which means with increase in age there is a decrease in T-score of BMD-lumbar spine and hip.

There was a positive correlation between age and urinary hydroxyproline: creatinine ratio which is statistically significant $(\mathrm{P}-\mathrm{value}<0.0001)$ which means with increase in age there is an increase in levels of urinary hydroxyproline: creatinine ratio (Table 2).

The mean serum calcium level of the study group was found to be $9.17 \pm 7.16 \mathrm{SD}$ and the correlation between BMI and serum calcium levels is not statistically significant with a P-value of 0.864 .

The mean ionised calcium level of the study group was found to be $1.037 \pm 0.05012$ and the correlation between $\mathrm{BMI}$ and ionised calcium levels is statistically significant with a $\mathrm{P}$-value of 0.006 .

Table 3: Correlation of BMI with serum phosphorus, ALP, serum albumin.

\begin{tabular}{|lllllll|}
\hline variable & $\begin{array}{l}\text { Underweight } \\
(\mathbf{n}=\mathbf{5})\end{array}$ & $\begin{array}{l}\text { Normal } \\
(\mathbf{n}=\mathbf{4 7})\end{array}$ & $\begin{array}{l}\text { Overweight } \\
(\mathbf{n}=\mathbf{3 9})\end{array}$ & $\begin{array}{l}\text { Obese } \\
(\mathbf{n}=\mathbf{9})\end{array}$ & $\begin{array}{l}\text { Total } \\
(\mathbf{n}=\mathbf{1 0 0})\end{array}$ & P-value \\
\hline $\begin{array}{l}\text { Serum phosphorus } \\
(\mathrm{mg} / \mathrm{dl})\end{array}$ & $4.420 \pm 0.334$ & $4.413 \pm 0.572$ & $4.413 \pm 0.5197$ & $4.289 \pm 0.416$ & $4.402 \pm 0.5249$ & $0.930, \mathrm{NS}$ \\
\hline $\begin{array}{l}\text { Alkaline } \\
\text { phosphatase (u/l) }\end{array}$ & $249.20 \pm 97.11$ & $265.04 \pm 42.46$ & $246.46 \pm 40.14$ & $260.56 \pm 30.414$ & $256.60 \pm 44.61$ & $0.274, \mathrm{NS}$ \\
\hline $\begin{array}{l}\text { Serum albumin } \\
(\mathrm{g} / \mathrm{dl})\end{array}$ & $3.680 \pm 0.216$ & $3.670 \pm 0.324$ & $3.746 \pm 0.253$ & $3.589 \pm 0.252$ & $3.693 \pm 0.2879$ & $0.427, \mathrm{NS}$ \\
\hline
\end{tabular}

NS: Not significant.

Table 4: Pearson correlation of BMI with all variables.

\begin{tabular}{|c|c|c|c|c|c|c|c|c|c|c|c|}
\hline & & Age & BMI & SC & IC & SP & ALP & S_ALB & BMD_LS & BMD_HIP & $\begin{array}{l}\text { URI - OH } \\
\text { Pr: create }\end{array}$ \\
\hline \multirow{2}{*}{ BMI } & $\begin{array}{l}\text { Pearson } \\
\text { correlation }\end{array}$ & 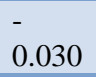 & 1 & -0.025 & $0.292 * *$ & -0.129 & 0.008 & -0.007 & $0.375 * *$ & $0.245^{*}$ & $-0.300 * *$ \\
\hline & $\begin{array}{l}\text { Sig. (2- } \\
\text { tailed) }\end{array}$ & 0.765 & & 0.807 & 0.003 & 0.201 & 0.940 & 0.945 & 0.000 & 0.014 & 0.002 \\
\hline
\end{tabular}

**Correlation is significant at the 0.01 level (2-tailed); *Correlation is significant at the 0.05 level (2-tailed).

Table 5: Correlation of BMD LS with BMI, serum calcium, ionised calcium.

\begin{tabular}{|c|c|c|c|c|c|}
\hline Variable & Normal $(n=24)$ & $\begin{array}{l}\text { Osteopenia } \\
(\mathrm{n}=4 \mathbf{5})\end{array}$ & $\begin{array}{l}\text { Osteoporosis } \\
(\mathbf{n}=\mathbf{3 1})\end{array}$ & Total $(n=100)$ & $\begin{array}{l}\text { P- } \\
\text { value }\end{array}$ \\
\hline BMI $\left(\mathrm{kg} / \mathrm{m}^{2}\right)$ & $25.88 \pm 4.65$ & $25.16 \pm 3.63$ & $23.28 \pm 4.49$ & $24.75 \pm 4.25$ & $0.052, \mathrm{NS}$ \\
\hline Serum calcium $(\mathrm{mg} / \mathrm{dl})$ & $8.39 \pm 0.29$ & $8.50 \pm 0.47$ & $10.77 \pm 12.8$ & $9.17 \pm 7.16$ & $0.332, \mathrm{NS}$ \\
\hline Ionized calcium (mmo 1/l) & $1.032 \pm 0.34$ & $1.045 \pm 0.58$ & $1.029 \pm 0.46$ & $1.037 \pm 0.501$ & $0.326, \mathrm{NS}$ \\
\hline
\end{tabular}

NS: Not significant.

The mean serum phosphorus level of the study group was found to be $4.402 \pm 0.524 \mathrm{SD}$ and the correlation between BMI and serum phosphorus levels is not found to be statistically significant with a P-value of 0.930 (Table 3 ).
The mean serum ALP level of the study group was found to be $256.60 \pm 44.614 \mathrm{SD}$ and the correlation between BMI and ALP is not statistically significant with a Pvalue of 0.274 . 
Table 6: Correlation of BMD LS with serum phosphorus, ALP, serum albumin.

\begin{tabular}{|c|c|c|c|c|c|}
\hline Variable & $\begin{array}{l}\text { Normal } \\
(\mathbf{n}=\mathbf{2 4})\end{array}$ & $\begin{array}{l}\text { Osteopenia } \\
(\mathbf{n}=\mathbf{4 5})\end{array}$ & $\begin{array}{l}\text { Osteoporosis } \\
(\mathbf{n}=\mathbf{3 1})\end{array}$ & Total $(n=100)$ & P-value \\
\hline Serum phosphorus (mg/dl) & $4.37 \pm 0.451$ & $4.344 \pm 0.57$ & $4.51 \pm 0.49$ & $4.40 \pm 0.52$ & $0.38, \mathrm{NS}$ \\
\hline Alkaline phosphatase $(\mathrm{u} / \mathrm{l})$ & $265.50 \pm 35.27$ & $248.02 \pm 37.74$ & $262.16 \pm 57.61$ & $256.60 \pm 44.61$ & $0.214, \mathrm{NS}$ \\
\hline Serum albumin $(\mathrm{g} / \mathrm{dl})$ & $3.66 \pm 0.244$ & $3.716 \pm 0.3015$ & $3.68 \pm 0.304$ & $3.639 \pm 0.287$ & $0.769, \mathrm{NS}$ \\
\hline
\end{tabular}

Table 7: Pearson correlation of BMD LS with all variables.

\begin{tabular}{|c|c|c|c|c|c|c|c|c|c|c|c|}
\hline & & Age & BMI & $\mathbf{S C}$ & IC & $\mathbf{S P}$ & ALP & S_ALB & $\begin{array}{l}\text { BMD_- } \\
\text { LS }\end{array}$ & $\begin{array}{l}\text { BMD_H } \\
\text { IP }\end{array}$ & $\begin{array}{l}\text { URI_- } \\
\text { hydr } 0\end{array}$ \\
\hline \multirow{2}{*}{$\begin{array}{l}\text { BMD } \\
\text { _LS }\end{array}$} & $\begin{array}{l}\text { Pearson } \\
\text { correlation }\end{array}$ & $-0.682 * *$ & $0.375 * *$ & -0.196 & 0.067 & -0.066 & -0.174 & 0.029 & 1 & $0.757 * *$ & $-0.783 * *$ \\
\hline & Sig & 0.000 & 0.000 & 0.051 & 0.509 & 0.513 & 0.083 & 0.777 & & 0.000 & 0.000 \\
\hline
\end{tabular}

$* *$ Correlation is significant at the 0.01 level (2-tailed), *Correlation is significant at the 0.05 level (2-tailed).

Table 8: Pearson correlation between all variables.

\begin{tabular}{|c|c|c|c|c|c|c|c|c|c|c|c|}
\hline & & Age & BMI & $\mathbf{S C}$ & $\mathbf{I C}$ & $\mathbf{S P}$ & $\mathbf{A L P}$ & S_ALB & $\begin{array}{l}\text { BMD_L } \\
\text { S }\end{array}$ & $\begin{array}{l}\text { BMD_ } \\
\text { HIP }\end{array}$ & $\begin{array}{l}\text { URI_- } \\
\text { hydro }\end{array}$ \\
\hline \multirow[t]{2}{*}{ Age } & $\begin{array}{l}\text { Pearson } \\
\text { correlation }\end{array}$ & 1 & -0.030 & 0.165 & -0.050 & 0.179 & 0.070 & -0.090 & - $0.682 * *$ & $\begin{array}{l}- \\
0.746 * *\end{array}$ & $0.643 * *$ \\
\hline & Sig. & & 0.765 & 0.100 & 0.622 & 0.075 & 0.487 & 0.374 & 0.000 & 0.000 & 0.000 \\
\hline \multirow[t]{2}{*}{ BMI } & $\begin{array}{l}\text { Pearson } \\
\text { correlation }\end{array}$ & -0.030 & 1 & -0.025 & $0.292 * *$ & -0.129 & 0.008 & -0.007 & $0.375 * *$ & $0.245^{*}$ & $-0.300 * *$ \\
\hline & Sig. & 0.765 & & 0.807 & 0.003 & 0.201 & 0.940 & 0.945 & 0.000 & 0.014 & 0.002 \\
\hline \multirow[t]{2}{*}{$\mathrm{SC}$} & $\begin{array}{l}\text { Pearson } \\
\text { correlation }\end{array}$ & 0.165 & -0.025 & 1 & -0.158 & -0.089 & $\begin{array}{l}0.198 \\
*\end{array}$ & -0.089 & -0.196 & -0.137 & $0.214^{*}$ \\
\hline & Sig. & 0.100 & 0.807 & & 0.116 & 0.380 & 0.048 & 0.379 & 0.051 & 0.173 & 0.033 \\
\hline \multirow[t]{2}{*}{ IC } & $\begin{array}{l}\text { Pearson } \\
\text { correlation }\end{array}$ & -0.050 & $0.292 * *$ & -0.158 & 1 & -0.145 & 0.004 & $0.376 * *$ & 0.067 & 0.020 & -0.068 \\
\hline & Sig. & 0.622 & 0.003 & 0.116 & & 0.151 & 0.970 & 0.000 & 0.509 & 0.845 & 0.501 \\
\hline \multirow[t]{2}{*}{ SP } & $\begin{array}{l}\text { Pearson } \\
\text { correlation }\end{array}$ & 0.179 & -0.129 & -0.089 & -0.145 & 1 & -0.031 & -0.065 & -0.066 & -0.194 & 0.027 \\
\hline & Sig. & 0.075 & 0.201 & 0.380 & 0.151 & & 0.760 & 0.522 & 0.513 & 0.053 & 0.792 \\
\hline \multirow[t]{2}{*}{ ALP } & $\begin{array}{l}\text { Pearson } \\
\text { correlation }\end{array}$ & 0.070 & 0.008 & $\begin{array}{l}0.198 \\
*\end{array}$ & 0.004 & -0.031 & 1 & 0.005 & -0.174 & -0.179 & $0.221 *$ \\
\hline & Sig & 0.487 & 0.940 & 0.048 & 0.970 & 0.760 & & 0.958 & 0.083 & 0.074 & 0.027 \\
\hline \multirow{2}{*}{$\begin{array}{l}\text { S_AL } \\
\text { B }\end{array}$} & $\begin{array}{l}\text { Pearson } \\
\text { correlation }\end{array}$ & -0.090 & -0.007 & -0.089 & $0.376^{* *}$ & -0.065 & 0.005 & 1 & 0.029 & 0.107 & 0.005 \\
\hline & Sig. & 0.374 & 0.945 & 0.379 & 0.000 & 0.522 & 0.958 & & 0.777 & 0.289 & 0.963 \\
\hline \multirow{2}{*}{$\begin{array}{l}\text { BMD } \\
\text { _LS }\end{array}$} & $\begin{array}{l}\text { Pearson } \\
\text { correlation }\end{array}$ & $\begin{array}{l}- \\
0.682 * *\end{array}$ & $0.375^{* *}$ & -0.196 & $\begin{array}{l}0.006 \\
7\end{array}$ & -0.066 & $\begin{array}{l}- \\
0.174\end{array}$ & 0.029 & 1 & $0.757 * *$ & $-0.783 * *$ \\
\hline & Sig. & 0.000 & 0.000 & 0.051 & 0.509 & 0.513 & 0.083 & 0.777 & & 0.000 & 0.000 \\
\hline \multirow{2}{*}{$\begin{array}{l}\text { BMD } \\
\text { _HIP }\end{array}$} & $\begin{array}{l}\text { Pearson } \\
\text { correlation }\end{array}$ & $\begin{array}{l}- \\
0.746 * *\end{array}$ & $\begin{array}{l}0.245 \\
*\end{array}$ & -0.137 & 0.020 & -0.194 & -0.179 & 0.107 & $0.757 * *$ & 1 & $-0.681 * *$ \\
\hline & Sig. & 0.000 & 0.014 & 0.173 & 0.845 & 0.053 & 0.074 & 0.289 & 0.000 & & 0.000 \\
\hline \multirow{2}{*}{$\begin{array}{l}\text { URI_- } \\
\text { OHPr: } \\
\text { creat }\end{array}$} & $\begin{array}{l}\text { Pearson } \\
\text { correlation }\end{array}$ & $0.643 * *$ & $-0.300^{* * 1}$ & $0.214^{*}$ & -0.068 & 0.027 & $\begin{array}{l}0.221 \\
*\end{array}$ & 0.005 & $-\overline{0.783 * *}$ & - $0.681 * *$ & 1 \\
\hline & Sig & 0.000 & 0.002 & 0.033 & 0.501 & 0.792 & 0.027 & 0.963 & 0.000 & 0.000 & \\
\hline
\end{tabular}

**Correlation is significant at the 0.01 level, *Correlation is significant at the 0.05 level.

The mean serum albumin of the study group was found to be $3.693 \pm 0.287 \mathrm{SD}$ and the correlation between BMI and serum albumin levels is not statistically significant with a $\mathrm{P}$-value of 0.427 .

The mean BMD Lumbar spine of the study group was found to be $-1.992 \pm 1.0971$ and the correlation between
BMI and BMD Lumbar spine is found to be statistically significant with a P-value of $<0.0001$ (Table 4).

The mean BMD Hip of the study group was found to be $1.14 \pm 0.9859$ and the correlation between BMI and BMD Hip is found to be statistically significant with a P-value of $<0.0001$. 
The mean urinary hydroxyproline: creatinine ratio of the study group was found to be $27.354 \pm 5.361$ and the correlation between BMI and urinary hydroxyproline: creatinine is found to be statistically significant with a $\mathrm{P}$ value of $<0.002$. Statistical analysis using Pearson correlation shows a positive correlation between BMI and T-score of BMD-lumbar spine and BMD-hip which is statistically significant.

There is a negative correlation observed between BMI and urinary hydroxyproline/creatinine ratio which is statistically significant which means with increase in BMI there is a decrease in levels of urinary hydroxyproline: creatinine.

There is a positive correlation found between BMI and ionised calcium which is statistically significant.

The mean age group of the study group was found to be $60.51 \pm 9.35$ and the correlation between BMD Lumbar spine and age is found to be statistically significant with a $\mathrm{P}$-value of $<0.0001$ (Table 5).

The mean BMI of the study group was found to be 24.75 $\pm 4.25 \mathrm{SD}$ and the correlation between BMD LS and $\mathrm{BMI}$ is not found to be statistically significant with a Pvalue of 0.052 (Table 5).

The mean serum calcium level of the study group was found to be $9.17 \pm 7.16 \mathrm{SD}$ and the correlation between BMD LS and serum calcium levels is not found to be statistically significant with a P-value of 0.332 .

The mean serum ionised calcium level of the study group was found to be $1.037 \pm 0.501 \mathrm{SD}$ and the correlation between BMD LS and serum ionised calcium levels is not found to be statistically significant with a P-value of 0.326 (Table 6).

The mean serum phosphorus level of the study group was found to be $4.40 \pm 0.52 \mathrm{SD}$ and the correlation between BMD LS and serum phosphorus levels is not found to be statistically significant with a P-value of 0.38 .

The mean serum ALP level of the study group was found to be $256.60 \pm 44.61 \mathrm{SD}$ and the correlation between BMD LS and serum ALP is not found to be statistically significant with a P-value of 0.214 .

The mean serum albumin level of the study group was found to be $3.693 \pm 0.287 \mathrm{SD}$ and the correlation between BMD LS and serum albumin levels is not found to be statistically significant with a P-value of 0.769 .

The mean BMD hip of the study group was found to be $1.14 \pm 0.98 \mathrm{SD}$ and the correlation between BMD LS and BMD hip is found to be statistically significant with a Pvalue of $<0.0001$.
The mean urinary hydroxyproline: creatinine ratio of the study group was found to be $27.35 \pm 5.36 \mathrm{SD}$ and the correlation between BMD LS and urinary hydroxyproline: creatinine is found to be statistically significant with a P-value of $<0.0001$.

- Statistical analysis using pearson correlation shows a significant negative correlation between BMD LS and age (Table 7)

- There is a significant positive correlation found between BMD LS and BMI

- There is a positive correlation observed between BMD LS and BMD hip which is statistically significant

- There is a negative correlation observed between BMD LS and urinary hydroxyproline/creatinine ratio which is statistically significant.

The mean age group of the study group was found to be $60.51 \pm 9.35$ and the correlation between BMD hip and age is found to be statistically significant with a P-value of $<0.0001$.

The mean BMI of the study group was found to be 24.75 $\pm 4.25 \mathrm{SD}$ and the correlation between BMD hip and $\mathrm{BMI}$ is found to be statistically significant with a P-value of 0.008 .

The mean serum ionised calcium level of the study group was found to be $1.037 \pm 0.501 \mathrm{SD}$ and the correlation between BMD hip and serum ionised calcium levels is not found to be statistically significant with a P-value of 0.538 .

The mean serum phosphorus level of the study group was found to be $4.402 \pm 0.524 \mathrm{SD}$ and the correlation between BMD hip and serum phosphorus levels is not found to be statistically significant with a P-value of 0.104 .

The mean serum albumin level of the study group was found to be $3.693 \pm 0.287 \mathrm{SD}$ and the correlation between BMD hip and serum albumin levels is not found to be statistically significant with a P-value of 0.178 .

The mean BMD LS of the study group was found to be $1.99 \pm 1.097 \mathrm{SD}$ and the correlation between BMD hip and BMD LS is found to be statistically significant with a Pvalue of $<0.0001$.

The mean urinary hydroxyproline/creatinine ratio of the study group was found to be $27.35 \pm 5.36 \mathrm{SD}$ and the correlation between BMD hip and urinary hydroxyproline/creatinine is found to be statistically significant with a P-value of $<0.0001$.

Statistical analysis using pearson correlation shows a significant negative correlation between BMD hip and age which is statistically significant. 
There is a significant positive correlation between BMD hip and BMI. There is a significant positive correlation between BMD HIP and BMD LS.

There is a negative correlation between BMD hip and urinary hydroxyproline: creatinine which is statistically significant (Table 8).

\section{DISCUSSION}

With increasing life expectancy, osteoporosis has become a formidable public health problem in the world as a whole. Data on prevalence of osteoporosis among women in India come from studies conducted in small groups spread across the country. Estimates suggest that of the 230 million Indians expected to be over the age of 50 years in $2015,20 \%$, i.e., about 46 million, are women with osteoporosis. ${ }^{5}$

Measurement of bone mineral density along with other risk factors can potentially improve the identification of osteopenic and osteoporotic women.

As per many studies there is a significant decrease in serum calcium levels in postmenopausal women compared to premenopausal women. In our study authors measured the serum calcium levels and correlated with age (40-80 year) among postmenopausal women.

In the study of Pardhe BD et al there was a significant correlation observed between age and ALP level with a P-value of 0.045 but in the studies by Rekha P et al, Sajjanar DS et al and Indumati $\mathrm{V}$ et al there was no significant correlation. In the present study also, there is no significant correlation observed. . $^{2,6,7}$

In our study also there is a significant correlation found with a P-value of 0.019 . This difference may be due to the changes in dietary intake of phosphorus and ethinicity.

In the studies by Rekha P et al, Sajjanar DS et al there was no significant correlation observed between age and serum albumin levels. ${ }^{6,7}$ Our study also is in accord with the above-mentioned studies with no significant correlation. According to many studies there is a significant decrease in ionized calcium levels in postmenopausal women compared to premenopausal women. In a study conducted by Indumati $\mathrm{V}$ et al there was a significant correlation observed between age and ionized calcium. ${ }^{3}$ In the present study there was observed a definitive decrease in ionized calcium levels with increasing age but with no statistical significance.

Monitoring bone status through urinary excretion of OHPr could serve as a surveillance measure for early intervention against excessive bone loss. In this study urinary hydroxyproline is expressed as $\mathrm{mg}$ of hydroxyproline/g of creatinine, because creatinine is excreted in the urine in relatively constant amounts proportional to an individual's muscle mass, thus serving as a reference standard. In the studies by Srirekha P et al, Sajjanar D et al showed a significant correlation between age and urinary hydroxyproline: creatinine levels. ${ }^{6,7}$ Bone formation outpaces resorption until peak bone mass is reached at around 30 years of age. ${ }^{2}$ Once the women is in her fourth decade, there is a gradual loss of bone mineral density. ${ }^{8}$ According to literature it was found that from the first year after menopause there is a progressive fall in bone density values up to 5 years. ${ }^{9}$ The strength of the present study is that BMD was measured using DEXA at two sites lumbar spine and the hip which enables to know where the loss was comparatively more.

In the previous studies, there was no significant correlation observed between BMI and serum calcium levels. Our study is in accord with above mentioned studies showing no significant correlation.

There were no studies in literature correlating BMI with ionized calcium. In the present study BMI with serum ionized calcium levels were also correlated and found to be significant

Higher intake of phosphorus is associated with a higher body mass index and waist circumference showing a direct relationship between phosphorus and BMI. ${ }^{10}$

A higher Ca: P-ratio in the diet is believed to prevent the reduction of bone loss and an important factor in calcium balance. In the study by Pardhe BD et al there was a significant correlation found between BMI and serum phosphorus levels where as no significant correlation was observed in the present study. ${ }^{2}$

In obesity, the activity of ALP is enhanced and ALP is released from adipose tissue into blood circulation in excessive amounts disproportionate to the intracellular fat depots. ${ }^{11}$ In the previous studies there was no significant correlation found between BMI and serum ALP levels. In our study also this observation holds true.

Urinary hydroxyproline is most important measure of bone resorption. In the present study authors found a correlation between BMI and urinary hydroxyproline: creatinine levels with a $\mathrm{P}$ value of 0.002 .

Osteoporosis usually doesn't have dramatic clinical presentation except when fractures occur. So, it is a silent epidemic. Tools like DEXA are used for screening women who are prone to osteoporosis enabling us to manage them in a better way. In elderly population it is important to review the hip scan as the spinal assessments are more likely to be falsely elevated.

In the present study the mean BMD of the underweight group is $-3.82 \pm 0.43$ at the level of lumbar spine and $2.88 \pm 0.21$ at the level of hip which is significantly lower than the BMD levels in overweight and obese group. This 
shows that low BMI is a risk factor and obesity is a protective factor for osteoporosis.

In our study the mean BMI of osteoporotic group is around $22 \mathrm{~kg} / \mathrm{m}^{2}$ found to be less than BMI of osteopenic and normal groups. In study by Sharma $\mathrm{S}$ et al, BMD at the level of forearm was measured and the study by Keen RW et al BMD at the level of femoral neck and spine are measured and correlated. ${ }^{12,13}$

In our study BMD at the level of lumbar spine and hip were measured using DEXA and authors found no significant correlation between BMD Lumbar spine and BMI and surprisingly significant correlation between BMD Hip and BMI was noted. This difference may be due to heterogenecity of BMD at different areas of body with different rates of osteoclastic activity which will be more in the early years of menopause leading to rapid bone loss at lumbar spine.

A low calcium: phosphorus intake has been reported to affect bone density with increased bone loss. In a study conducted by Sharma $\mathrm{S}$ et al there was no significant correlation observed between BMD and serum phosphorus. ${ }^{12}$ The present study is in accord with the above study showing no significant correlation.

Alkaline phosphatase is a ubiquitous enzyme that plays an important role in osteoid formation and mineralization and can be used as a marker of bone formation. Estrogen deficiency at the menopause increases the rate of bone remodeling, which results in high turnover bone loss. So the levels of alkaline phosphatase increases in postmenopausal women compared to pre menopause. A study by Keen RW et al, showed no significant correlation between BMD lumbar spine and femoral neck and serum ALP levels. ${ }^{13}$ In present study there is no correlation observed between BMD and alkaline phosphatase.

According to some studies there is a relationship between dietary protein intake and peak bone mass in women. In a study by Erasmo ED et al, there was no significant correlation observed between serum albumin levels and bone mineral density at lumbar spine and hip. ${ }^{14}$ The present study is in accord with the previous study showing no significant correlation.

The level of hydroxyproline which is principally a resorption marker has significantly increased in urine in postmenopausal women with osteoporosis. The increase in hydroxyproline indicates degradation of type 1 collagen of bone and indirectly indicates the decrease in BMD. ${ }^{15}$

In the present study there is a significant correlation observed between BMD and OHPr. This may be explained by difference in the age groups taken in both the studies i.e., 46-60 years in Civitelli et al, and 40-80 years in the present study and also the ethinicity of recruited population. ${ }^{16}$

Osteoporosis is generally regarded as a reduction in total bone mineral density, although at individual level, the extent of osteoporosis may show heterogenecity. In studies conducted by Keen RW et al, there was a significant correlation observed between BMD LS and BMD HIP. ${ }^{13}$ In present study using Pearson correlation authors also found that there is a significant positive correlation between BMD lumbar spine and BMD hip.

\section{CONCLUSION}

Osteoporosis is a bone metabolic syndrome with reduction in bone mass and decrease in bone strength resulting in bone fragility and fractures.

There are about 200 million people suffering from osteoporosis worldwide. Because of increased life span, one third of life is spent in estrogen deficient period leading to increased morbidity and mortality due to osteoporosis. Osteoporosis is a major concern of public health because of its health care cost.

BMD measurements using DEXA are not readily available in India. Biochemical markers of bone remodelling are useful tools in assessment of osteoporosis and are safe, inexpensive, easily performed. In the present study an attempt is made to correlate biochemical markers and BMD so as to detect osteoporosis even before the changes being evident on imaging studies.

\section{The present study arrived at the following conclusions}

Negative correlation being observed between age and BMD. Positive correlation observed between BMI and BMD.

Negative correlation between BMD and urinary hydroxyproline, thus hydroxyproline can be used as a marker of resorption for diagnosis and monitoring the treatment in places where imaging facilities for BMD estimation are not available. Early osteoporotic changes can be detected in the lumbar spine BMD compared to hip.

Funding: No funding sources

Conflict of interest: None declared

Ethical approval: The study was approved by the Institutional Ethics Committee

\section{REFERENCES}

1. Watts NB. Postmenopausal osteoporosis: a clinical review. J Women's Health. 2018.

2. Pardhe BD, Pathak S, Bhetwal A, Ghimire S, Shakya S, Khanal PR, et al. Effect of age and estrogen on biochemical markers of bone turnover in 
postmenopausal women: a population-based study from Nepal. Int J Women's Health. 2017;9:781-8.

3. Indumati V, Patil VS, Jailkhani R. Hospital based preliminary study on osteoporosis in postmenopausal women. Indian J Clin Biochem. 2007;22(2):96-100.

4. Bhattachaeyya S, Siegel ER, Achenbach SJ, Khosla S, Suva LJ. Serum biochemical profile associated with high bone turnover and BMD in postmenopausal women. J Bone Mineral Res. 2008;23.

5. Sharma S, Agarwal B, Sharma R, Singh S. Forearm bone mineral density in postmenopausal Indian women: correlation with calcium nutrition. 2017;6(10):4339-46.

6. Rekha P, Venkateswarulu U, Sarada U. Comparative study of biochemical bone turn over markers in pre and postmenopausal women. Int $\mathbf{J}$ Applied Res. 2015;1(5):185-7.

7. Sajjanar DS, Sajjanar SL. Study of serum alkaline phosphatase, calcium and urinary hydroxyproline as bone biomarkers in postmenopausal women. Int J Basic Appl Med Sci. 2014;4(1):223-9.

8. Gandhi A, Shukla AK. Evaluation of BMD of women above 40 years of age. J Obstet Gynecol India. 2005;55(3):265-7.

9. Isaia G, Mussetta M, Di Stefano M, Sciolla A, Triolo S, Molinatti GM. Metabolic markers for the early diagnosis of postmenopausal osteoporosis. J Endocrinol Invest. 1994;17(10):771-4.

10. de Carvalho Pereira D, Lima RP, de Lima RT, Gonçalves MD, de Morais LC, Franceschini SD, et al. Association between obesity and calcium: phosphorus ratio in the habitual diets of adults in a city of Northeastern Brazil: an epidemiological study. Nutrit J. 2013;12(1):90.

11. Khan AR, Awan FR, Najam S, Islam M, Siddique T, Zain M. Elevated serum level of human alkaline phosphatase in obesity. Age (years). 2015;48(8.8):42-5.

12. Sharma S, Agarwal B, Sharma R, Singh S. Forearm bone mineral density in postmenopausal Indian women: correlation with calcium nutrition. Int $\mathbf{J}$ Reprod Contracept Obstet Gynecol. 2017;6:4339-46.

13. Keen RW, Nguyen T, Sobnack R, Perry LA, Thompson PW, Spector TD. Can biochemical markers predict bone loss at the hip and spine?: a 4year prospective study of 141 early postmenopausal women. Osteoporosis Int. 1996;6(5):399-406.

14. D'Erasmo E, Pisani D, Ragno A, Raejntroph N, Letizia C, Acc M. Relationship between serum albumin and bone mineral density in postmenopausal women and in patients with hypoalbuminemia. Horm Metab Res. 1999;31:385-8.

15. Kuo TR, Chen $\mathrm{CH}$. Bone biomarker for the clinical assessment of osteoporosis: recent developments and future perspectives. Biomarker Res. 2017;5(1):18.

16. Civitelli R, Gonnelli S, Zacchei F, Bigazzi S, Louis $\mathrm{AV}$, Gennarit C. Bone turnover in postmenopausal osteoporosis. J Clin Invest. 1988;82(4):1268-74.

Cite this article as: Hymavathi $\mathrm{K}$, Jakka T, Paturi B. Correlation of biomarkers and bone mineral density for osteoporosis in post-menopausal women. Int $\mathbf{J}$ Reprod Contracept Obstet Gynecol 2020;9:720-8. 